\title{
PENGARUH LAMA PERENDAMAN DENGAN PERASAN JERUK LEMON DAN GARAM DAPUR TERHADAP KADAR PROTEIN TAHU
}

\author{
Nastiti Kartikorini ${ }^{1}$ \\ ${ }^{1)}$ Prodi D3 Analis, FIK, Universitas Muhammadiyah Surabaya \\ nastitikartikorini@gmail.com
}

Tangal Submit:

29 November 2017

Tanggal Review:

8 Desember 2017

Tanggal Publish Online: 12 Desember 2017

\begin{abstract}
Tofu is one of the healthy foods because of the relatively high protein content. In know that stored at room temperature will only last for 1-2 days. Therefore, many sellers know who gives the formalin to preserve know. Whereas the use of formaldehyde is very harmful for health. One of the efforts to secure the preservation know that the provision of $10 \%$ lemon juice and salt to $4 \%$ who will preserve up to 6 days at room temperature. Just know that the old storage can cause denaturation of proteins which can result in decreased levels of protein out. This study aims to investigate the influence of soaking in lemon juice and salt to the protein content out. The protein content was obtained through laboratory know the Micro-Kjeldahl method. The sample was 8 were divided into 4 groups: control, know by soaking for 1 day, 3 days and 6 days. To determine the effect of soaking the protein content out statistical analysis used ANOVA and continued to LSD. The results of the data analysis ANOVA test showed that there was no effect of soaking time with the lemon juice and salt to the protein content of tofu ( $\mathrm{p}$ values> 0.05). Average protein content know that soaked for 1 day $13.24 \%, 12.78 \%$ and 3 days 6 days $12.34 \%$. So it can be concluded that aging out with lemon juice and salt has no effect on protein levels out. Therefore preservation know this way is relatively safe and does not reduce the levels of proteins out.
\end{abstract}

Keywords: tofu, lemon, protein level

\section{PENDAHULUAN}

Makanan adalah salah satu kebutuhan dasar manusia. Dalam kehidupan sehari-hari manusia tidak terlepas dari makanan. Sebagai kebutuhan dasar makanan tersebut harus mengandung zat gizi untuk dapat memenuhi fungsinya dan dapat dikonsumsi karena makanan yang tidak aman akan menimbulkan gangguan kesehatan bahkan keracunan (Sjahmien, 1992).
Salah satu makanan yang mengandung zat gizi adalah tahu. Tahu merupakan makanan yang populer di masyarakat Indonesia walaupun asalnya dari Cina. Kepopuleran tahu tidak hanya terbatas karena rasanya yang enak, tetapi juga mudah untuk membuatnya dan dapat diolah menjadi berbagai bentuk masakan serta harganya yang murah. 
Selain itu, tahu merupakan salah satu makanan yang menyehatkan karena kandungan protein yang cukup tinggi. Kandungan protein pada kedelai berkisar 35$43 \%$ atau hampir menyamai kandungan protein pada susu bubuk, sehingga tahu berpotensi sebagai makanan pengganti untuk orang yang tidak boleh makan daging atau susu.

Tahu merupakan suatu produk yang terbuat dari hasil penggumpalan protein kedelai. Protein yang terkandung di dalam kedelai ini bisa dicerna secara efektif oleh tubuh manusia. (AgroMedia, 2007). Tahu juga mengandung zat gizi lainnya seperti vitamin, lemak, dan mineral dalam jumlah tinggi (Winarno, 1983).

Selain memiliki kelebihan, tahu juga memiliki kelemahan yaitu memiliki kandungan air yang tinggi sehingga membuat tahu mudah rusak (mudah ditumbuhi mikroba). Disimpan pada kondisi biasa (suhu ruang) daya tahannya rata-rata hanya 1-2 hari saja. Setelah lebih dari batas tersebut rasanya menjadi asam dan berangsur-angsur busuk. Akibatnya banyak usaha yang dilakukan produsen tahu untuk mengawetkannya, termasuk menggunakan bahan yang dilarang, misalnya formalin.

Perubahan yang dapat terlihat dari luar apabila telah mengalami kerusakan, yaitu mengeluarkan bau asam sampai busuk, permukaan tahu berlendir, tekstur menjadi lunak, kekompakan berkurang, warna dan penampakan tidak cerah, kadang-kadang berjamur pada permukaannya (Fardiaz dkk, 1988). Sedangkan ciri - ciri tahu yang mengandung formalin adalah tahu tidak rusak sampai tiga hari pada suhu ruang dan bertahan lebih dari 15 hari pada suhu dingin, tahu keras namun tidak padat, dan baunya agak menyengat khas formalin (Mujadjanto, 2005).

Beberapa bahan pengawet yang digunakan selama ini adalah formalin, asam benzoat dan sebagai antioksidan adalah BHT, BHA, TBHQ dan lain-lain bersumber dari bahan minyak bumi atau sintesis (Deiana M, 2003; Shahidi, 2003). Penggunaan bahan pengawet dan antioksidan sintetis pada saat ini tidak direkomendasikan oleh Departemen Kesehatan karena diduga dapat menyebabkan penyakit kanker (Hernani; Mono Raharjo, 2005).

Bahan pengawet alami merupakan jenis pengawet yang memiliki banyak khasiat, terutama sebagai bahan pengawet makanan. Bahan pengawet alami relatif aman dibandingkan bahan pengawet sintetis (Winarno; Rahayu, 1994). Bahan pengawet alami ini hampir terdapat pada semua tumbuhtumbuhan dan buah-buahan tersebar di seluruh tanah air yang mengandung zat antimikroba yang khas misalnya asam sitrat yang banyak ditemukan pada buah-buahan.

Sumber dari Asam Sitrat terdapat pada berbagai jenis buah dan sayuran. Misalnya dalam jeruk lemon dan limau (jeruk nipis dan jeruk purut). Dalam $100 \mathrm{~g}$ jeruk manis, misalnya, mengandung energi $51 \mathrm{kal}$, protein 0,9 g, lemak 0,2 g, karbohidrat 11,4 g, kalsium 
$33 \mathrm{mg}$, fosfor $23 \mathrm{mg}$, besi $0,4 \mathrm{mg}$, vitamin A (retinol) $190 \mathrm{IU}$ atau $57 \mathrm{mcg}$, vitamin B1 0,08 $\mathrm{mg}$, asam askorbat (vitamin C) $49 \mathrm{mg}$ serta air 87,2 gr.

Buah jeruk dan aneka produk olahan berbahan dasar jeruk pada dasarnya juga mengandung senyawa flavonoid dan limonoid yang diyakini bermanfaat untuk melawan berbagai penyakit. Senyawa flavonoid utama yang terkandung dalam buah jeruk adalah naringin dan untuk limonoid adalah limonin. Dari sejumlah penelitian yang dilakukan para pakar ahli menunjukkan bahwa kandungan senyawa limonin dalam buah jeruk berkhasiat sebagai zat antimalaria antimikroba, serta mampu menurunkan level kolesterol dalam darah (Handoko, 2011).

Berdasarkan hasil penelitian Ria Mariana Mustafa dari Instititut Pertanian Bogor 2006 diperoleh bahwa perlakuan penambahan bahan pengawet alami yang efektif pada penyimpanan suhu dingin adalah perlakuan kombinasi antara garam $4 \%$ dan jeruk nipis $1,4 \%$. Perlakuan tersebut memiliki nilai ratarata total mikroba terkecil, $\mathrm{pH}$ tahu dan larutan perendam tahu yang semakin meningkat selama masa penyimpanan, skor rata-rata tertinggi terhadap kesukaan aroma, warna, rasa, dan penerimaan umum serta masih dapat mengawetkan tahu kurang lebih delapan sampai 10 hari.

Menurut Koswara, pengawetan tahu selain menggunakan formalin dapat dilakukan dengan menggunakan campuran perasan jeruk lemon $10 \%$ dan garam dapur $4 \%$. Maka tahu dapat awet hingga 10 hari pada suhu ruang.

Penambahan asam dengan $\mathrm{NaCl}$ merupakan suatu bentuk kombinasi zat aktif pengawet yang diharapkan akan sinergis dalam mengawetkan tahu dan meningkatkan penerimaan rasa pada tahu. Asam yang digunakan terdapat pada jeruk yang dapat menurunkan $\mathrm{pH}$ suatu makanan sehingga dapat menghambat pertumbuhan bakteri pembusuk (Supardi, 1999).

Berdasarkan uraian diatas, dapat diketahui manfaat jeruk lemon yang cukup banyak maka hal ini merupakan upaya untuk mengurangi penggunaan formalin sehingga dapat meminimalisir bahaya formalin.

Rumusan Masalah dalam penelitian ini adalah Adakah pengaruh lama perendaman dengan perasan jeruk lemon dan garam dapur terhadap kadar protein tahu. Tujuan Penelitian ini adalah Menganalisis kadar protein tahu yang direndam dengan perasan jeruk lemon dan garam dapur. Dan Mengetahui pengaruh lama perendaman dengan perasan jeruk lemon dan garam dapur terhadap kadar protein tahu.

\section{METODE PENELITIAN}

Jenis penelitian yang digunakan adalah Eksperimental yang bertujuan untuk mengetahui adanya pengaruh lama perendaman dengan perasan jeruk lemon dan garam dapur terhadap kadar protein tahu. Dengan Rancangan penelitian menurut Hidayat (2010), sebagai berikut: 


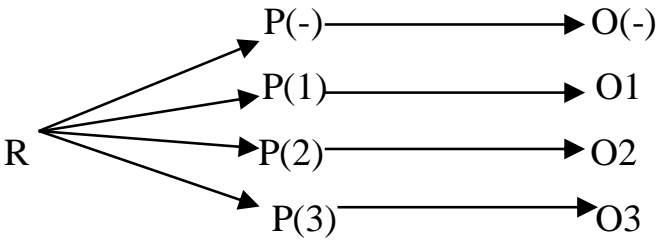

Keterangan:

R : Random

$\mathrm{P}(-)$ : Perlakuan tanpa perendaman perasan jeruk lemon dan garam dapur

$\mathrm{P}(1)$ : Perlakuan dengan perendaman perasan jeruk lemon dan garam dapur selama 1 hari.

$\mathrm{P}(2)$ : Perlakuan dengan perendaman perasan jeruk lemon dan garam dapur selama 3 hari.

$\mathrm{P}(3)$ : Perlakuan dengan perendaman perasan jeruk lemon dan garam dapur selama 6 hari.

$\mathrm{O}(-)$ : Observasi kadar protein tahu tanpa perlakuan

O1 : Observasi kadar protein tahu dengan perendaman selama 1 hari.

O2 : Observasi kadar protein tahu dengan perendaman selama 3 hari.

O3 : Observasi kadar protein tahu dengan perendaman selama 6 hari.

Populasi dalam penelitian ini adalah tahu yang dijual di Pasar Mulyosari Surabaya. Sampel yang digunakan sebanyak 8 sampel tahu yang masing-masing akan diperlakukan dengan 4 perlakuan. Sehingga jumlah sampel yang diperiksa berjumlah 32 sampel. Pengambilan sampel tahu dipilih tahu yang masih segar atau baru datang dari pabrik.

Pengambilan sampel tahu dilakukan di pasar Mulyosari Surabaya. Untuk pemeriksaan sampel tahu dilakukan di BPKI Surabaya (Balai Penelitian dan Konsultasi Industri). Penelitian dilakukan pada bulan Februari sampai dengan bulan Juli 2012, sedangkan pemeriksaan sampel dilakukan tanggal pada tanggal 03 sampai 10 Mei 2012.

Variabel bebasnya adalah Lama perendaman dengan perasan jeruk lemon dan garam dapur. Perendaman dengan perasan jeruk lemon dan garam dapur dalam penelitian ini dikategorikan menjadi lamanya perendaman selama 1 hari, 3 hari dan 6 hari. Variabel terikatnya adalah Kadar protein tahu, angka yang menunjukkan kandungan protein yang terdapat pada tahu berdasarkan metode Kjeldahl-Mikro dalam satuan \%. Hasilnya akan dibandingkan dengan kontrol (tanpa perlakuan).

Data yang dikumpulkan dari penelitian adalah jumlah perasan jeruk lemon dengan cara pemeriksaan di laboratorium pada sampel tahu dengan menganalisa kadar protein dalam tahu ditetapkan berdasarkan metode kjeldahlmikro. Prinsip Pemeriksaan dengan penetapan protein berdasarkan oksidasi bahan-bahan berkarbon dan konversi nitrogen menjadi amonia. Selanjutnya amonia bereaksi dengan kelebihan asam membentuk amonium sulfat. Larutan dibuat menjadi basa, dan amonia diuapkan untuk kemudian diserap dalam larutan asam borat. Nitrogen yang terkandung dalam larutan dapat ditentukan jumlahnya dengan titrasi menggunakan $\mathrm{HCl} 0,1 \mathrm{~N}$.

Alat atau Instrumen Pemeriksaan antara lain Alat Destilasi kjeldahl, Labu kjeldahl berukuran $30 \mathrm{ml} / 50 \mathrm{ml}$, Buret $25 \mathrm{ml} / 50 \mathrm{ml}$, Labu didih, Pipet volume. Bahan dan Reagen Pemeriksaan $\mathrm{H}_{2} \mathrm{SO}_{4}$ pekat, $\mathrm{K}_{2} \mathrm{SO}_{4}, \mathrm{HgO}, \mathrm{HCl}$, Larutan natrium hidroksida-natrium thiosulfat (larutkan $60 \mathrm{~g} \mathrm{NaOH}$ dan $5 \mathrm{~g} \mathrm{Na}_{2} \mathrm{~S}_{2} \mathrm{O}_{3} .5 \mathrm{H}_{2} \mathrm{O}$ dalam air dan encerkan sampai $100 \mathrm{ml}$ ), Indikator (campuran 2 bagian methyl merah $0,2 \%$ dalam alkohol dan 1 bagian methylene blue $0,25 \%$ dalam alkohol), Larutan $\mathrm{H}_{2} \mathrm{BO}_{3}$ jenuh, Aquadest. 
Pembuatan larutan campuran jeruk lemon $10 \%$ dan garam dapur $(\mathrm{NaCl}) 4 \%$ yaitu dengan Dua buah jeruk lemon diperas dan ditampung pada beaker glass dan menimbang garam dapur sebanyak $4 \mathrm{~g}$. Selanjutnya dipipet $10 \mathrm{ml}$ perasan jeruk lemon tersebut, kemudian masukkan dalam beaker glass bersih. Campurkan dengan 4 g garam dapur dan larutkan dengan sedikit aquadest. Tuang larutan tersebut dalam labu ukur $100 \mathrm{ml}$ dan di add-kan dengan aquadest hingga batas miniskus.

Perlakuan Sampel Tahu, Semua tahu yang berjumlah $\quad 8 \quad$ kemudian masing-masing diperlakukan, yaitu kontrol, tahu dengan perendaman selama 1 hari, 3 hari dan 6 hari. Selanjutnya, tahu disimpan dalam kantong plastik dan direndam dengan larutan campuran jeruk lemon dan garam dapur hingga bagian tahu terendam semua kemudian kantong plastik diikat dan disimpan pada suhu ruang. Lakukan pengujian kadar protein tahu sesuai masing-masing kelompok yang sudah ditentukan.

Sebelum dilakukan pengujian kadar protein dilakukan Standarisasi $\mathrm{HCl}$ dengan Larutan Baku NaOH 0,1000N. Pengujian Kadar Protein dilakukan dengan menimbang 1 gram bahan yang telah dihaluskan dan masukkan kedalam labu kjeldahl. Kemudian tambahkan 1,9 $\mathrm{g} \mathrm{K}_{2} \mathrm{SO}_{4}, 40 \mathrm{mg} \mathrm{HgO}$, dan 2,0 $\mathrm{ml} \mathrm{H} 2 \mathrm{SO} 4$. Kemudian ditambahkan beberapa batu didih dan dididihkan sampel selama 11,5 jam sampai cairan menjadi jernih. Lalu didinginkan dan ditambahkan sejumlah kecil air secara perlahan-lahan kemudian didinginkan. Isi labu dipindahkan kedalam alat destilasi. Cuci dan bilas labu 5-6 kali dengan 1-2 ml aquadest. Selanjutnya, erlenmeyer 125 ml yang berisi $5 \mathrm{ml}$ larutan $\mathrm{H}_{2} \mathrm{BO}_{3}$ dan 2-4 tetes indikator diletakkan dibawah kondensor. Ujung tabung kondensor harus terendam dibawah larutan $\mathrm{H}_{2} \mathrm{BO}_{3}$, Ditambahkan 8-10 ml larutan $\mathrm{NaOH}-\mathrm{Na}_{2} \mathrm{~S}_{2} \mathrm{O}_{3}$, kemudian dilakukan destilasi sampai tertampung $15 \mathrm{ml}$ destilat dalam Erlenmeyer. Tabung kondensor dibilas dengan aquadest, dan bilasannya ditampung dalam Erlenmeyer yang sama. Isi Erlenmeyer diencerkan sampai $50 \mathrm{ml}$ kemudian di titrasi dengan $\mathrm{HCl} \quad 0,1000 \quad \mathrm{~N}$ sampai terjadi perubahan warna menjadi abu-abu. Lakukan juga penetapan untuk blanko.

Dengan Perhitungan:

$\% \mathrm{~N}=\frac{(\mathrm{ml} \mathrm{HCl}-\mathrm{ml} \text { blanko }) \times \text { Normalitas } \times 0,014 \times 5,71 \times 100 \%}{\mathrm{~g} \text { sampel }}$

Keterangan:

Faktor kacang kedelai $=5,71$

Normalitas $=$ Normalitas $\mathrm{HCl}$

$\mathrm{g}$ sampel $=\mathrm{g}$ tahu yang digunakan setelah perlakuan Berat atom Nitrogen $=14=0,014$ (satuan g)

(Sumber: Departemen Perindustrian, 1998)

\section{HASIL PENELITIAN}

Hasil analisis kadar protein tahu di Balai Penelitian dan Konsultasi Industri laboratorium diperoleh hasil sebagai berikut. 
Tabel 1. Kadar Protein Tahu yang direndam dengan Perasan Jeruk Lemon dan Garam Dapur.

\begin{tabular}{|l|l|l|l|l|l|}
\hline \multirow{2}{*}{ No. } & Kode & \multicolumn{5}{|c|}{ Kadar Protein $(\%)$} \\
\cline { 3 - 6 } & Sampel & Kontrol & 1 hari & 3 hari & 6 hari \\
\hline 1. & 1 & 14,11 & 14,10 & 14,05 & 13,68 \\
\hline 2. & 2 & 12,88 & 12,81 & 12,82 & 12,36 \\
\hline 3. & 3 & 11,56 & 11,56 & 11,50 & 11,05 \\
\hline 4. & 4 & 13,82 & 13,80 & 13,82 & 13,60 \\
\hline 5. & 5 & 13,58 & 13,44 & 12,88 & 12,59 \\
\hline 6. & 6 & 14,08 & 13,90 & 13,07 & 12,43 \\
\hline 7. & 7 & 12,90 & 12,65 & 11,32 & 11,02 \\
\hline 8. & 8 & 14,09 & 13,69 & 12,80 & 12,04 \\
\hline \multicolumn{2}{|l}{ Jumlah } & 107,02 & 105,95 & 102,26 & 98,77 \\
\hline \multicolumn{2}{|l}{ Rata-rata } & 13,3775 & 13,2438 & 12,7825 & 12,3463 \\
\hline Sd & 0,89069 & 0,85244 & 0,96810 & 0,99645 \\
\hline
\end{tabular}

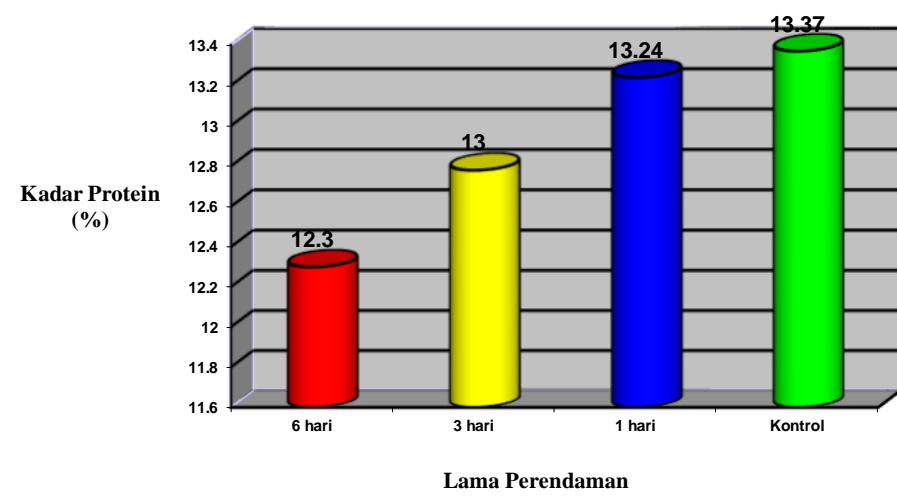

Gambar 1. Grafik Batang Kadar Protein Tahu

Berdasarkan uji distribusi terhadap hasil analisis kadar protein tahu dari data penelitian tersebut didapatkan bahwa data terdistribusi normal. Hal ini ditunjukkan dengan nilai $\mathrm{p}=$ 0,854 lebih besar dari $\alpha 0,05(\mathrm{p}>\alpha)$ pada ratarata kadar protein tahu yang tidak dilakukan perendaman, sedangkan pada 1 hari perendaman nilai $\mathrm{p}=0,849$ lebih besar dari $\alpha$ $0,05(\mathrm{p}>\alpha)$, pada 3 hari perendaman nilai $\mathrm{p}=$ 0,665 lebih besar dari $\alpha 0,05(\mathrm{p}>\alpha)$ dan pada 6 hari perendaman nilai $\mathrm{p}=0,992$ lebih besar dari $\alpha 0,05 \quad(p>\alpha)$. Hasil uji menunjukkan bahwa data terdistribusi normal, maka dilanjutkan ke uji anova. Analisis anova bertujuan untuk mengetahui pengaruh variable bebas (perendaman dengan perasan jeruk lemon dan garam dapur) terhadap kadar protein tahu. Dari hasil uji Anova menunjukkan bahwa tidak ada pengaruh perendaman dengan perasan jeruk lemon dan garam dapur selama 1 hari, 3 hari dan 6 hari.

Diketahui nilai $\mathrm{F}$ hitung 2.044 dengan nilai probabilitas (sig.) $\mathrm{p}=0.131$ dimana lebih besar dari 0,05 sehingga Ha ditolak, artinya tidak ada pengaruh perendaman dengan perasan jeruk lemon dan garam dapur terhadap kadar protein tahu. Untuk mengetahui sejauh mana perbedaan rata-rata kadar protein antar kelompok (1 hari, 3 hari dan 6 hari) dilakukan analisis LSD.

\section{PEMBAHASAN}

Dari hasil penelitian yang dilakukan pada bulan Februari - Juni 2012, diperoleh hasil yang tidak berbeda signifikan antara kadar protein tahu yang direndam dengan perasan jeruk lemon dan garam dapur selama 1 hari, 3 hari dan 6 hari. Rata-rata kadar protein tertinggi terdapat pada tahu yang direndam selama 1 hari yaitu $13,2438 \%$, sedangkan rata-rata kadar protein terendah terdapat pada tahu yang direndam selama 6 hari yaitu $12,3463 \%$.

Berdasarkan uji distribusi terhadap hasil analisis kadar protein tahu dari data penelitian tersebut didapatkan bahwa data terdistribusi normal. Sedangkan uji statistik anova menunjukkan tidak adanya pengaruh 
yang signifikan antara lama perendaman pada suhu kamar dengan kadar protein tahu. Hal ini ditunjukkan dengan nilai $\mathrm{p}>0,05$ yaitu 0,854 . Untuk mengetahui sejauh mana perbedaan rata-rata antara kelompok dilakukan analisa LSD. Data hasil LSD dapat diketahui bahwa urutan rata-rata kadar protein yang tertinggi sampai terendah adalah selama selama 1 hari 13,24\%, 3 hari 12,78\% dan 6 hari 12,34\%.

Tidak adanya pengaruh yang signifikan terhadap kadar protein tahu tersebut disebabkan karena adanya kombinasi penambahan asam dan garam yang bersifat mengawetkan dan tidak merusak kadar protein tahu tersebut.

Penggunaan asam dalam pengolahan bahan makanan mempunyai peranan penting yang bersifat antimikroba. Hal ini dikarenakan penambahan asam akan mempengaruhi $\mathrm{pH}$ disamping juga adanya sifat menghambat pertumbuhan mikroba yang khas dari hasil urainya. Toksisitas asam yang ditimbulkan sangat bervariasi bergantung kepada kondisi keasamannya (Supardi 1999).

Kandungan asam sitrat pada jeruk lemon mampu mengendalikan $\mathrm{pH}$ larutan sehingga sangat efektif untuk menghambat pertumbuhan mikroba.

Sedangkan, garam juga mempengaruhi aktivitas air (aw ᄀ) dari bahan sehingga mengendalikan pertumbuhan mikroorganisme dengan suatu metode yang bebas dari pengaruh racunnya (Buckle dkk, 1987). Penggunaan garam juga tergantung dari jenis bahan pangan yang diawetkan walaupun dengan semakin tingginya konsentrasi garam yang digunakan dapat menghambat pertumbuhan mikroba. Pada konsentrasi $\mathrm{NaCl}$ sebesar 2-5\% yang dikombinasikan dengan suhu rendah, cukup untuk mencegah pertumbuhan mikroba psikrofilik (Supardi, 1999). Selain itu, penggunaan garam sebagai bahan pengawet akan mempengaruhi penerimaan rasa dari jenis pangan, terutama tahu yang mempunyai rasa tawar dan rasa yang khas.

Mekanisme pengawetan $\mathrm{NaCl}$ adalah dengan memecahkan (plasmolisis) membran sel mikroba, karena $\mathrm{NaCl}$ mempunyai tekanan osmotik yang tinggi. Disamping itu, $\mathrm{NaCl}$ bersifat hidroskopis sehingga dapat menyerap air dari bahan yang mengakibatkan aw dari bahan tersebut menjadi rendah. Selain itu $\mathrm{NaCl}$ dapat mengurangi kelarutan oksigen, sehingga mikroba aerob dapat dicegah pertumbuhannya (Supardi, 1999).

Oleh karena itu, pemberian perasan lemon dan garam dapur sangat membantu dalam proses pengawetan karena relatif aman, tidak memiliki efek kimia dan tidak mengurangi kadar protein secara signifikan.

\section{KESIMPULAN}

Dari pemeriksaan yang dilakukan terhadap 32 sampel tahu didapatkan kesimpulan bahwa rata-rata kadar protein tahu yang tertinggi sampai terendah berturut-turut pada lama penyimpanan selama 1 hari $(13,24 \%), 3$ hari $(12,78 \%)$ dan 6 hari $(12,34 \%)$. Tidak ada pengaruh lama 
perendaman dengan perasan jeruk lemon dan garam dapur terhadap kadar protein tahu.

Bagi Masyarakat disarankan untuk mengawetkan tahu agar tahan lebih lama sebaiknya meggunakan pengawet jeruk lemon $10 \%$ dan garam dapur $4 \%$ maka tahu akan tahan hingga 6 hari pada suhu ruang. Bagi peneliti sejenis supaya diadakan penelitian tentang pengaruh lama perendaman perasan jeruk lemon dan garam dapur pada konsentrasi maupun penyimpanan yang berbeda.

\section{DAFTAR PUSTAKA}

Deiana M., A. Rosa., V. Casu., F. Cotiglia., L. Bonsing More and M.A. Dessi. 2003. Chemical Composition and Antioxidant Activity of Extract from Dephegnidium L. JAOCS. 801 65-70

Naharsari, N,D. 2007. Bercocok Tanam Jeruk. Azka Mulia Media : Jakarta

Shahidi, F, Desilva, C and Amarowiz, R. 2003. Antioxidant Activity of Extract of Defatted Seeds of Niger (Goizotia Abyssinica). JOACS. 80. 5. 443-450

Handoko, Haryo Bagus, SP. 2011. Makanan Awet Muda dan Panjang Umur. PT Elex Media Komputindo : Jakarta

Harmoni, D. 2006. Seluk Beluk Formalin. www.hd.co.id

Herawati, Dian dkk. 2011. Analisis Pangan. Dian Rakyat : Jakarta
Hernani dan Mono Raharjo., 2005, "Tanaman Berkhasiat Antioksidan" Penerbit Swadaya, Jakarta.

Kompas. 2005. Keamanan Pangan. www.kompas.com

Kompas. 2005. Waspadai Adanya Makanan Berformalin. www.kompas.com

Koswara, S. Mengawetkan Tahu Tanpa Formalin. Institut Pertanian Bogor

Mustafa, R.M. 2006. Studi Efektivitas Bahan Pengawet Alami Dalam Pengawetan Tahu. Institut Pertanian Bogor (IPB)

Mudjajanto. 2005. Tahu, Makanan Favorit Yang Perlu Diwaspadai. www.kompas.com

$\begin{array}{ccc}\text { 2000. Peningkatan Proses dan } \\ \text { Kemasan } & \text { Tahu. } & \text { Departemen }\end{array}$
Perindustrian dan Perdagangan

Redaksi AgroMedia. 2010. Membuat Tahu dan Tempe. PT AgroMedia Pustaka : Jakarta

Republika. 2005. Hindarkan Pemakaian Legal Formalin untuk Pangan. http://www.republika.co.id

Republika. 2005. Perusahaan Tahu Takwa Poo di Kediri Berencana Gugat Balai POM. http://www.republika.co.id

Sarwono, B dan Yan Pieter. 2005. Membuat Aneka Tahu. Penebar Swadaya : Jakarta

SNI 01- 3142-1992

Suprapti, Lies. 1997. Dasar-dasar Teknologi Pangan. Vidi Ariesta : Surabaya

Winarno, F.G. 2004. Kimia Pangan Dan Gizi. PT Gramedia Pustaka Utama : Jakarta 